\title{
Legal personhood of Latin American rivers: time to shift constitutional paradigms?
}

\author{
Amaya Álvez-Marín \\ Associate Professor, Department of Public Law, Faculty of Law and Social Science, University of Concepción
}

Camila Bañales-Seguel

Doctoral Researcher, Faculty of Environmental Sciences, University of Concepción

Rodrigo Castillo

Research Assistant, Water Research Center for Agriculture and Mining, University of Concepción

Claudia Acuña-Molina

Lawyer, University of Concepción

Pablo Torres*
Lawyer, University of Concepción

Diverse existing legal paradigms have dealt with the interaction of humans and Nature in different ways. We identify three main lenses through which current constitutional systems in Latin America have operated to resolve conflicts. We focus on rivers as emblematic elements of Nature that offer concrete possibilities to operationalize an emerging paradigm that recognizes legal personhood for Nature. The objective is to examine, from a critical interdisciplinary perspective, the existing paradigms, describe their limits and open the debate to alternative jurisdictional venues for favouring the coexistence of humans and natural systems. Through the comparative analysis of three case studies in Chile, Colombia and Ecuador, we outline the challenges and opportunities offered by an emerging legal tradition, 'The New Latin American Constitutionalism', and question what would effectively be different with a change of paradigm towards the recognition of Nature's rights.

Keywords: rights of Nature, river rights, Latin American Constitutionalism, legal pluralism, river management

\section{INTRODUCTION}

Humanity is already facing the social-ecological effects of the climate crisis. Despite the warnings from the scientific community to avoid the encroaching of

* We thank the two anonymous reviewers, the journal's editors and our colleague Diego Rivera for their feedback to improve the discussion presented in this manuscript. The participation of Amaya Álvez-Marín and Rodrigo Castillo was funded by Fondap Project ANID/FONDAP/ 15130015. Camila Bañales-Seguel was supported by the Agencia Naiconal de Investigación (ANID) PhD grant $\mathrm{n}^{\circ}$ 2018-21190264. 
environmental limits, ${ }^{1}$ continued demographic growth and consumption is jeopardizing our future. ${ }^{2}$ Today, it is recognized that the health of the living planet is both a prerequisite and basis for economic prosperity and the health and well-being of humans. $^{3}$

The current paradigm of the commodification of Nature,${ }^{4}$ which has resulted in this social-ecological crisis, relies upon a conceptualization of Nature as an objectifiable provider of 'natural resources' ${ }^{5}$ a conceptualization justifying the domination, alteration and exploitation of the natural world. However, for socio-ecological systems to continue with some semblance of stability, a deep transformation of this commodification paradigm is needed. ${ }^{6}$

The conception of Nature as an object has justified a development model that has reached such levels of ecological predation that humans are considered to be a 'global geological force with destructive and self-destructive capacities'. ${ }^{7}$ A central part of this destruction of Nature is due to the extraction of natural resources, an especially intense process in Latin American economies. ${ }^{8}$

Any new paradigm and associated development model(s) seeking to address these issues must constrain economic goals within the boundaries of natural systems, underwritten by legal structures which protect both these ecological limits as well as humans' dignity and quality of life. It will also be necessary to allow for a plurality of development models, since cultures hold different ways of valuing and relating to the world. ${ }^{9}$

The present article focuses on water, and specifically on rivers as natural entities that reflect the larger dynamics of environmental protection. Through jurisprudential developments, the assignment of legal personhood to rivers has been leading a trend at the international level, with several emblematic cases in the last decade. ${ }^{10}$ Indeed, fluvial ecosystems offer diverse possibilities for solving the challenges of the operationalization of rights of Nature. We propose a critical examination and comparison of existing

1. Johan Rockström and others, 'A Safe Operating Space for Humanity' (2009) 461 Nature. 2. William J Ripple and others, 'World Scientists' Warning to Humanity: A Second Notice' [2017] BioScience 1.

3. UNEP, 'GEO-6 Key Messages' (2019).

4. Maristella Svampa, 'Commodities Consensus: Neoextractivism and Enclosure of the Commons in Latin America' (2015) 114 South Atlantic Quarterly 65.

5. Esperanza Martinez, La Naturaleza Entre La Cultura, La Biología y El Derecho (1st edn, Editorial Abya-yala 2014); Digno Montalván, 'Justicia Ecológica' (2020) 18 Eunomia. Revista en Cultura de la Legalidad 179; Svampa (n 4).

6. Alberto Acosta, 'Hacia La Declaración de Los Derechos de La Naturaleza. Reflexiones Para La Acción' (2010) 54 AFESE 11.

7. Alejandro Medici, 'Ecological Liberation: On the Recognition and Foundation of the Rights of Nature in the New Transformational Constitutionalism' (2017) 1(2) Revista Sobre Accesso à Justiça e Direitos nas Américas 141.

8. Eduardo Gudynas, 'Concepciones de La Naturaleza y Desarrollo En América Latina' (1999) 13 Persona y Sociedad. Universidad Alberto Hurtado 101; Eduardo Gudynas, 'Buen Vivir: Today's Tomorrow' (2011) 54 Development 441; Ramiro Avila, 'Los Derechos de La Naturaleza Desde El Pensamiento Crítico Latinoamericano' (2014) <http://repositorio.uasb. edu.ec/bitstream/10644/4057/1/PI-2008-08-Velásquez-Conceptos Jurídicos.pdf>.

9. Christiana Zenner, 'Valuing Fresh Waters' (2019) 6 Wiley Interdisciplinary Reviews: Water e1343; Gudynas, 'Concepciones de La Naturaleza y Desarrollo En América Latina' (n 8).

10. Lidia Cano Pecharroman, 'Rights of Nature: Rivers that Can Stand in Court' (2018) 7 Resources 13; Erin L O'Donnell and Julia Talbot-Jones, 'Creating Legal Rights for Rivers: Lessons from Australia, New Zealand, and India' (2018) 23 Ecology and Society. 
Latin American constitutional paradigms and reflect on three case studies that offer useful elements to deal with the challenges of the emerging paradigm of the rights of Nature. Each case study consists of a court ruling that is representative of a particular form of regulation of Nature: the recognition of Nature's rights at the constitutional level (Vilcabamba River, Ecuador); court recognition of biocultural rights (Atrato River, Colombia); and the conception of Nature as an object of regulation and of private rights (Loa River, Chile).

Each case reached the respective country's Constitutional Court, the highest judicial level. Constitutional framing is decisive in the decisions adopted by the courts, because the constitutions provide the paradigm used to analyze the legal protection and well-being of rivers. The paradigms analyzed, as reflected through cases in Chile, Colombia and Ecuador, show how the implementation of the rights of Nature at the constitutional level demands challenging the way in which Nature's protection is understood.

We attempt to weave an interdisciplinary dialogue in order to open the discussion around this central question: What elements of judicial cases concerning Latin American rivers, as a representation of current existing constitutional paradigms, can nurture the operationalization of the global trend towards granting Nature legal personhood?

\subsection{Current legal paradigms for coexistence with Nature}

The main Western paradigm by which social coexistence has been approached since the mid-nineteenth century is the language of human rights, a perspective that aspires to be universal and to ensure human life under decent conditions of subsistence. ${ }^{11}$ A key advancement in the regulation of life conditions is the human right to safe drinking water and sanitation. ${ }^{12}$ Yet, the legal paradigm of human rights has not avoided incremental risks on a global scale related to access to water. ${ }^{13}$ This evidence points to the urgent need to reconfigure the way water is conceived, valued and managed. ${ }^{14}$

One example of an attempt to include Nature in the legal system using the human rights paradigm is provided by the human right to an environment free of contamination, such as exists in the Chilean Constitution of 1980. However, at the same time, the Chilean Constitution displays a conception of Nature as an object and provides de facto human ownership of natural resources. ${ }^{15}$ The problem with this approach is that

11. Pedi Obani and Joyeeta Gupta, 'Legal Pluralism in the Area of Human Rights: Water and Sanitation' (2014) 11 Current Opinion in Environmental Sustainability $63<\mathrm{http}$ ://dx.doi.org/ 10.1016/j.cosust.2014.09.014>; Klaus Bosselmann, 'Human Rights and the Environment: Redefining Fundamental Principles?' in B Gleeson and N Low (eds), Governing for the Environment (Palgrave Macmillan 2001).

12. Emanuele Fantini, 'An Introduction to the Human Right to Water: Law, Politics, and Beyond' (2020) 7 WIREs Water 1.

13. World Economic Forum, 'The Global Risks Report 2020' (2020)<http://wef.ch/ risks2019> accessed 10 November 2020.

14. Eduardo Gudynas, 'La Senda Biocéntrica: Valores Intrínsecos, Derechos de La Naturaleza y Justicia Ecológica' [2010] Tabula Rasa 45; Zenner (n 9); Rutgerd Boelens and Jeroen Vos, 'Legal Pluralism, Hydraulic Property Creation and Sustainability: The Materialized Nature of Water Rights in User-Managed Systems' (2014) 11 Current Opinion in Environmental Sustainability 55 .

15. Jessica Budds, 'Securing the Market: Water Security and the Internal Contradictions of Chile's Water Code' (2020) 113 Geoforum 165 <https://doi.org/10.1016/j.geoforum.2018.09.027>; 
it does not solve the tensions of the neoliberal extractivism model. ${ }^{16}$ Under this model rights such as private property rights and economic development rights tend to overrule considerations about the preservation of Nature, even when the human right to live in an environment free of contamination is affected. One route for dealing with this tension is through legal protection mandates to protect natural entities, detailing quality standards and the rights of non-humans, such as the protection of animals. ${ }^{17}$ In terms of water regulation, the Chilean Constitution and Water Code have proved to be insufficient. Not only has the Chilean approach maintained significant inequalities, but it has also been marked by increasing levels of competition among users (including non-humans, people and industries), and lacks a recognition of the intrinsic ecological relationship between the water cycle and Nature's health.

On the other hand, the paradigm of rights of Nature proposes a view that is collective, integrated, relational and ecocentric. ${ }^{18}$ This view has been incorporated in the Constitutions of Bolivia ${ }^{19}$ and Ecuador ${ }^{20}$ as part of strategies for the recovery of natural commons. These two apparently antagonistic views of water are presented by Andreas Fischer-Lescano. ${ }^{21}$ The latter view considers Nature as holding autonomous and intrinsic value in itself; while the former view measures its value based on the utility provided to humans. ${ }^{22}$

By proposing a new reading of the theory of human rights, Klaus Bosselmann ${ }^{23}$ advocates for a situated vision of human rights. This approach allows for the establishment

Verónica Delgado and others, 'El Amparo de Aguas En La Jurisprudencia Chilena (2013-2015)' [2018] Revista Derecho del Estado 197 <http://www.scielo.org.co/scielo.php?script=sci_arttext\& pid=S0122-98932018000200197\&lang=pt\%0Ahttp://www.scielo.org.co/pdf/rdes/n41/0122-9893rdes-41-00197.pdf>; Lilian Galdamez, 'Medio Ambiente, Constitución y Tratados En Chile' (2017) Año XLX Boletín Mexicano de Derecho Comparado. UNAM, Instituto de Investigaciones Jurídicas. 113.

16. Galdamez (n 15).

17. Juan Pablo Mañalich Raffo, 'Animalidad y Subjetividad. Los Animales (No Humanos) Como Sujetos-de-Derecho' (2018) 31 Revista de Derecho 321.

18. Santiago Vallejo, 'La Considerabilidad Moral: Fundamento Ético Del Reconocimiento de La Naturaleza Como Sujeto de Derecho' [2019] Letras Verdes. Revista Latinoamericana de Estudios Socioambientales 11.

19. Eduardo Gudynas, 'Development Alternatives in Bolivia: The Impulse, the Resistance, and the Restoration' (2013) 46 NACLA Report on the Americas 22; Rickard Lalander, 'Rights of Nature and the Indigenous Peoples in Bolivia and Ecuador: A Straitjacket for Progressive Development Politics?' [2015] SSRN Electronic Journal; Alfredo Romero-Muñoz and others, 'A Pivotal Year for Bolivian Conservation Policy' (2019) 3 Nature Ecology and Evolution 866. 20. Eduardo Gudynas, 'The Political Ecology of the Biocentric Turn in Ecuador's New Constitution' (2009) 32 Revista de Estudios Sociales 34; Juan Pablo Hidalgo, Rutgerd Boelens and Jeroen Vos, 'De-Colonizing Water. Dispossession, Water Insecurity, and Indigenous Claims for Resources, Authority, and Territory' (2017) 9 Water History 67; Sarah A Radcliffe, 'Development for a Postneoliberal Era? Sumak Kawsay, Living Well and the Limits to Decolonisation in Ecuador' (2012) 43 Geoforum 240 <http://dx.doi.org/10.1016/j.geoforum.2011.09.003>; Daniel Bonilla, 'El Constitucionalismo Radical Ambiental y La Diversidad Cultural En América Latina. Los Derechos de La Naturaleza y El Buen Vivir En Ecuador y Bolivia' [2019] Revista Derecho del Estado 3.

21. A Fischer-Lescano, 'Nature as a Legal Person: Proxy Constellations in Law' (2020) 32 Law and Literature 2.

22. Anthony Burke, 'Blue Screen Biosphere: The Absent Presence of Biodiversity in International Law' (2019) 13 International Political Sociology 333.

23. Bosselmann (n 11). 
of general limitations to the rights (especially to property rights) associated with environmental conservation. It also allows for developing a rights system guided by the understanding that environmental conservation is an indispensable condition for the full exercise of all human rights, as well as for the very survival of the human species. ${ }^{24}$ Relatedly, the vision of the rights of Nature that has emerged in Latin American constitutions could be seen as a re-interpretation of traditional concepts of modern constitutionalism in the light of other forms of knowledge ${ }^{25}$ and of local identities.

In the Latin American context, Godofredo Stutzin has been a pioneer in considering the idea of legal personhood of Nature to be useful for the configuration of an 'ecological right' associated with the idea of a 'heritage' or 'patrimony' of the natural world. ${ }^{26}$ Stutzin explains that given Nature's condition as counterpart to humanity in every aspect, Nature holds a character of legal personhood that is both supranational and omnipresent, and whose rights can and should be respected at all levels from the global to the local. This legal personhood conception means that Nature can be understood as a 'Foundation for Life', ${ }^{27}$ which has been created (or has created itself) to make planet Earth home to living beings. Just like all foundations, Nature is composed of a heritage or patrimony, which in this case includes the totality of the natural world, animate and inanimate, which carries out a function in the 'business of life'. ${ }^{28}$ We consider this conceptualization to be a way to overcome the anthropocentric idea of a 'right to the environment', understood as relative to the human environment, and to move towards the recognition of intimate interdependence between human rights and Nature's protection. These Latin American ideas provide a biocentric turn ${ }^{29}$ and are opposed to the objectification of Nature and to extractivism, allowing for the optimal protection of natural entities.

Nonetheless, the paradigm of rights of Nature today faces a series of challenges. In addition to the limited progress in their effective implementation, their institutional weakness, and the inadequacy of the legal systems in which they receive recognition, ${ }^{30}$ there are also criticisms at the theoretical level regarding the possible conflicts that

24. Aled Dilwyn Fisher and Maria Lundberg, "Human Rights" Legitimacy in the Face of the Global Ecological Crisis - Indigenous Peoples, Ecological Rights Claims and the Inter-American Human Rights System' (2015) 6 Journal of Human Rights and the Environment 177; Andrew N Kadykalo and others, 'Disentangling "Ecosystem Services" and "Nature's Contributions to People"” (2019) 15 Ecosystems and People 269 <https://doi.org/10.1080/26395916.2019.1669713>.

25. Bonilla (n 20).

26. Godofredo Stutzin, 'Un Imperativo Ecológico: Reconocer Los Derechos de La Naturaleza' (1984) 1 Ambiente y Desarrollo 97; Godofredo Stutzin, 'La Naturaleza de Los Derechos y Los Derechos de La Naturaleza', Congreso Nacional de Derecho del Entorno. Universidad Católica de Valparaíso. 18-20 de agosto de 1977 (1978); Godofredo Stutzin, 'Die Natur Der Rechte Und Die Rechte Der Natur' (1980) 3 Rechtstheorie.

27. Stutzin, 'Un Imperativo Ecológico: Reconocer Los Derechos de La Naturaleza' (n 26).

28. ibid.

29. Gudynas, 'Concepciones de La Naturaleza y Desarrollo En América Latina' (n 8); Gudynas, 'La Senda Biocéntrica: Valores Intrínsecos, Derechos de La Naturaleza y Justicia Ecológica' (n 14); Antonio Carlos Wolkmer, María de Fátima Wolkmer and Debora Ferrazzo, 'Derechos de La Naturaleza: Para Un Paradigma Político y Constitucional Desde La América Latina' in Liliana Estupiñan Achury and others (eds), La Naturaleza como sujeto de derechos en el constitucionalismo democrático (Universidad Libre 2019); Esperanza Martínez and Alberto Acosta, 'Los Derechos de La Naturaleza Como Puerta de Entrada a Otro Mundo Posible’ (2017) 8 Revista Direito e Práxis 2927.

30. Erin O'Donnell and Elizabeth Macpherson, 'Voice, Power and Legitimacy: The Role of the Legal Person in River Management in New Zealand, Chile and Australia' (2019) 23 Australian Journal of Water Resources 35. 
might arise between the fundamental rights of humans and the rights of Nature. This possibility fuels a tension between the two types of rights from a legal perspective. ${ }^{31}$

Rivers - as paradigmatic natural entities - could be used as a proxy for studying how a constitutional order fosters or impedes a healthy relationship between humans and Nature. The recognition of the rights of Nature as a whole, or as particular entities within the ecosystem, is also an element of the debate. The notion that rivers are entities whose legal personhood can be recognized is emphasized by the interdependence that exists between humans and rivers (as structuring components of societies and of the quality of life of these communities). Indeed, studying rivers as socio-ecological systems, where the human dimension is an inseparable component of a broader system, is becoming a standard theoretical framework. ${ }^{32}$

\subsection{Rivers as rights bearers}

Fluvial ecosystems have been at the heart of some of the most emblematic cases pushing forward the frontier of what has been called a 'rights revolution for Nature'. ${ }^{33}$ This 'revolutionary' shift is displayed, for example, by the case of the Whanganui River in New Zealand, whose legal personhood was recognized through a legal entity called Te Awa Tupua (Whanganui River Claims Settlement) Act 2017 New Zealand. ${ }^{34}$ Similarly, there is the case of the Atrato River, located in Colombia, which was recognized in 2016 as an entity with legal personhood and the right to be protected, conserved, maintained and restored. ${ }^{35}$

Fluvial ecosystems have different types of hierarchical levels of organization in geomorphological, hydrological and ecological dimensions. It is very difficult to establish a truly holistic framework to study the health of any particular river, much less to characterize all rivers. ${ }^{36}$ Thus, the functioning and health of a river must be evaluated on a case-by-case basis. Depending on the guidelines and scope of an investigation, management measure or legal definition, pertinent variables should be selected according to the applicable criteria of relevance, scale

31. Erin O’Donnell, Legal Rights for Rivers: Competition, Collaboration and Water Governance (Routledge 2018).

32. Violeta Cabello and others, 'River Basins as Social-Ecological Systems: Linking Levels of Societal and Ecosystem Water Metabolism in a Semiarid Watershed' (2015) 20 Ecology and Society art 20.

33. Guillaume Chapron, Yaffa Epstein and Jose Vicente Lopez-Bao, 'A Rights Revolution for Nature' (2019) 363 Science Magazine 1392; Cano Pecharroman (n 10).

34. Liz Charpleix, 'The Whanganui River as Te Awa Tupua: Place-Based Law in a Legally Pluralistic Society’ (2018) 184 The Geographical Journal 19 <http://doi.wiley.com/10.1111/ geoj.12238>.

35. Judgment T-622-16 of the Constitutional Court; Diego Cagüeñas, María Isabel Galindo Orrego and Sabina Rasmussen, 'The Atrato River and its Guardians: Ecopolitical Imagination for Weaving New Rights' (2020) 56 Revista Colombiana de Antropologia 169; Yuber PalaciosTorres, Jesus D de la Rosa and Jesus Olivero-Verbel, 'Trace Elements in Sediments and Fish from Atrato River: An Ecosystem with Legal Rights Impacted by Gold Mining at the Colombian Pacific' (2020) 256 Environmental Pollution $113290<$ https://doi.org/10.1016/j. envpol.2019.113290>.

36. Carla L Atkinson and others, 'Incorporating Ecogeomorphic Feedbacks to Better Understand Resiliency in Streams: A Review and Directions Forward' (2018) 305 Geomorphology 123. 
and sensitivity. ${ }^{37}$ For example, the ecosystem function of organic matter decomposition is of high relevance for a study focused on small streams, but of limited relevance for large rivers. ${ }^{38}$ On the other hand, the sensitivity of the same ecosystem function is different for different human alterations: very sensitive to channeling; medium sensitivity to flow regulation; and low sensitivity to deforestation. ${ }^{39}$ The diverse characteristics of rivers demand close attention from normative systems to the particularities of each river and their basins. This necessitates a consideration of multiple factors while avoiding the imposition of a uniform treatment, thus aiming for the appropriability of regulation to each case.

River well-being is critical for sustaining natural biodiversity and ecosystem integrity. ${ }^{40}$ However, currently only 23 per cent of large rivers (longer than $1000 \mathrm{~km}$ ) worldwide conserve their uninterrupted natural flow regime on their way from the headwaters to the mouth. ${ }^{41}$ The complexity of environmental problems that rivers face in the current global scenario demands a deep understanding of the impacts of historical and present human activities. ${ }^{42}$ The main human activities that impact rivers are the agriculture, forestry and mining industries; and urbanization, along with and the construction of engineering works such as pipelines, reservoirs and transportation routes. ${ }^{43}$ The construction of reservoirs and dams is the main cause of the loss of connectivity in rivers due to consequent flow regulation and fragmentation. ${ }^{44}$ Human consumptive uses of water result in competition with the requirements for ecosystem functioning, ${ }^{45}$ for example: 75 per cent of fresh water worldwide is destined for agricultural production. ${ }^{46}$ These activities trigger processes such as erosion, salinization, eutrophication and aggravation of river channels and river mouths, which alter the geomorphological and chemical equilibria and the composition of aquatic communities. Aquatic communities are composed of riparian vegetation, algae and biofilms, mollusks, aquatic insects, fish and aquatic mammals. They constitute the tissue of life in rivers and provide support for key ecological functions. ${ }^{47}$ These equilibriums and communities are part of the 'patrimony' of rivers to which Stutzin referred. ${ }^{48}$

37. Arturo Elosegi and Sergi Sabater, 'Effects of Hydromorphological Impacts on River Ecosystem Functioning: A Review and Suggestions for Assessing Ecological Impacts' (2013) 712 Hydrobiologia 129.

38. ibid.

39. ibid.

40. N LeRoy Poff and others, 'The Natural Flow Regime' (1997) 47 BioScience 769 <https:// academic.oup.com/bioscience/article-lookup/doi/10.2307/1313099>.

41. G Grill and others, 'Mapping the World's Free-Flowing Rivers' (2019) 569 Nature 215. 42. Ellen Wohl, 'Forgotten Legacies: Understanding and Mitigating Historical Human Alterations of River Corridors' (2019) 55 Water Resources Research 5181.

43. Mark Macklin and John Lewin, 'River Stresses in Anthropogenic Times: Large-Scale Global Patterns and Extended Environmental Timelines' [2018] Progress in Physical Geography 1; Grill and others (n 41).

44. Grill and others (n 41); Ellen Wohl and others, 'Connectivity as an Emergent Property of Geomorphic Systems' (2019) 44 Earth Surface Processes and Landforms 4.

45. C Vörösmarty and others, 'Fresh Waters', in Ecosystems and Human Well-being: Current State and Trends: Findings of the Condition and Trends Working Group (Island Press 2019). 46. IPBES, 'Summary for Policymakers of the Global Assessment Report on Biodiversity and Ecosystem Services' (2019) <https://www.ipbes.net/system/tdf/spm_global_unedited_advance. pdf? file $=1 \&$ type $=$ node $\&$ id $=35245>$.

47. Atkinson and others (n 36); Elosegi and Sabater (n 37).

48. Stutzin, 'Un Imperativo Ecológico: Reconocer Los Derechos de La Naturaleza' (n 26). 
Current river science is interdisciplinary and moves towards the recognition of the dynamic feedback cycles between both physical and biological processes, ${ }^{49}$ focusing on the resilience of rivers as an essential property ${ }^{50}$ while conceptualizing humans as a component of socio-ecological systems. ${ }^{51}$ River science has, however, a role beyond the analysis of the impacts of human activities on rivers and their aquatic communities. From a legal point of view, scientific disciplines that study river functioning contribute concepts and principles that can be used in court rulings or developing regulations to define the rights of rivers. There is significant jurisprudence that conceptualizes rivers as objects under the law. ${ }^{52}$ Such decisions (in the sense of judicial decisions and therefore 'rules') can be used as a measuring stick to determine whether or not the new rulings that understand Nature as a subject produce a change to legal conceptualizations.

In this context, a necessary starting point to determine parameters for healthy rivers is the concept of the Natural Flow Regime, which characterizes the uninterrupted flow of a river and how it varies according to differing time scales (hours, days, years, decades). ${ }^{53}$ This regime is essential for ecological integrity as it regulates water quality, energy sources, physical habitat and biotic interactions. Recent advances have broadened the understanding of the Natural Flow Regime to include sediment and wood transported by rivers as integral elements of river functioning. ${ }^{54}$ These configure the geomorphology of river channels, influencing stream velocity and determining water quality and nutrient availability, and ultimately, the potential habitat for different species. Connectivity (longitudinal, lateral, vertical and temporal) is also a key property of resilient rivers. ${ }^{55}$ In consideration of this, two concepts are crucial to safeguard river connectivity, but could additionally contribute to defining river rights. The first is the concept of 'freedom space', meaning the physical expanse that a river needs to occupy throughout its natural fluctuations at different temporal scales. This notion highlights the lateral connectivity of a river to its riparian space, such as wetlands and frequently flooded adjacent areas. ${ }^{56}$ Legal frameworks that consider floodplains to be part of the river could yield better territorial planning and reduce risk for human settlements. Second, the hyporheic zone focuses on the vertical connectivity between the active channel,

49. Ellen Wohl, 'Time and the Rivers Flowing: Fluvial Geomorphology since 1960' (2014) 216 Geomorphology 263.

50. MC Thoms, H Piégay and M Parsons, 'What Do You Mean, "Resilient Geomorphic Systems"?' (2018) 305 Geomorphology 8.

51. Cabello and others (n 32); Jason B Dunham and others, 'Rivers Are Social-Ecological Systems: Time to Integrate Human Dimensions into Riverscape Ecology and Management' (2018) 5 Wiley Interdisciplinary Reviews: Water e1291; Martin Thoms and Fran Sheldon, 'Large Rivers as Complex Adaptive Ecosystems' (2019) 35 River Research and Applications 451.

52. Svampa (n 4); Budds (n 15); Carl Bauer, Siren Song: Chilean Water Law as a Model for International Reform (1st edn, Resources for the Future 2004).

53. Poff and others (n 40); N LeRoy Poff, 'A River that Flows Free Connects up in 4D' (2019) 569 Nature 201.

54. Ellen Wohl and others, 'The Natural Wood Regime in Rivers' (2019) 69 BioScience 259; Ellen Wohl and others, 'The Natural Sediment Regime in Rivers: Broadening the Foundation for Ecosystem Management' (2015) 65 BioScience 358.

55. Ellen Wohl and others, 'Connectivity as an Emergent Property of Geomorphic Systems' (2019) 44 Earth Surface Processes and Landforms 4.

56. Thomas Buffin-Bélanger and others, 'Freedom Space for Rivers: An Economically Viable River Management Concept in a Changing Climate' (2015) 251 Geomorphology 137. 
the alluvial plain and the groundwater. ${ }^{57}$ The hyporheic zone is the porous transition between the river channel, the river bed, and the underground water table. This part of the river structure is essential for the mixing of surface water and of shallow groundwater, as well as offering a habitat for many aquatic species.

The most recent macro-ecosystem perspectives incorporate an understanding of large-scale functioning by emphasizing the importance of patterns of tributaries and confluences (Network Dynamic Hypothesis ${ }^{58}$ ) and the heterogeneous nature of rivers at multiple scales. ${ }^{59}$ These perspectives combine traditional approaches with theories of landscape ecology, coining the concept of a 'riverscape' ${ }^{60}$ The heterogeneity of a riverscape is an attribute of river integrity that can be the object of protection or of regenerative measures through legal mechanisms such as court rulings, or through the measures and plans of administrative authorities.

\subsection{Ontological-epistemological pluralism}

Scientific disciplines that study rivers should have a central role in the definition of norms, measures and plans to manage rivers. However, advancements in scientific knowledge have often obscured other types of knowledge as part of the so-called 'civilizing mission'. ${ }^{61}$

Scientific knowledge is considered legitimate because it rests on two fundamental pillars: it is acquired through logical reasoning and it is obtained from empirical observation. ${ }^{62}$ However, the valuation of the scientific method as the only valid way to acquire knowledge is an expression of culture. Essentially, it is culture that determines what is important and valid in terms of observing, understanding and making sense of reality. ${ }^{63}$ Early travel chronicles from Europeans visiting distant lands helped to characterize indigenous peoples as savages. This characterization not only served to legitimize violence against Indigenous territories and communities, but in the long

57. Atkinson and others (n 36).

58. L Benda and others, 'The Network Dynamics Hypothesis: How Channel Networks Structure Riverine Habitats' (2004) 54 BioScience 5.

59. James H Thorp, Martin C Thoms and Michael D Delong, 'The Riverine Ecosystem Synthesis: Biocomplexity in River Networks across Space and Time' (2006) 22 River Research and Applications 123; AM Gurnell and others, 'A Multi-Scale Hierarchical Framework for Developing Understanding of River Behaviour to Support River Management' (2016) 78 Aquatic Sciences $1<\mathrm{http} / / /$ link.springer.com/10.1007/s00027-015-0424-5>; Barbara Belletti and others, 'Characterising Physical Habitats and Fluvial Hydromorphology: A New System for the Survey and Classification of River Geomorphic Units' (2017) 283 Geomorphology $143<$ http://dx.doi. org/10.1016/j.geomorph.2017.01.032>.

60. Kurt Fausch and others, 'Landscapes to Riverscapes: Bridging the Gap between Research and Conservation of Stream Fishes' (2006) 52 BioScience 483.

61. Arun Agrawal, 'Indigenous Knowledge and the Politics of Classification' (2002) 54 International Social Science Journal 287; Arun Agrawal, 'Dismantling the Divide Between Indigenous and Scientific Knowledge' (1995) 26 Development and Change $413<$ http://doi.wiley.com/10.1111/ j.1467-7660.1995.tb00560.x>; Silvia Rivera Cusicanqui, 'Ch'ixinakax Utxiwa: A Reflection on the Practices and Discourses of Decolonization' (2012) 111 South Atlantic Quarterly 95.

62. Coyan Tromp, Wicked Philosophy: Philosophy of Science and Vision Development for Complex Problems (1st edn, Amsterdam University Press 2018).

63. Mai Nguyen-Phuon-Mai, 'The Evolving Culture', in Intercultural Communication. An Interdisciplinary Approach: When Neurons, Genes and Evolution Joined the Discourse (2nd edn, Amsterdam University Press 2018). 
term, it has led to a lesser-valuation of knowledge held by Indigenous people, since this form of knowledge is seen through the binary lens of 'civilized-barbaric'.

Recently, increasing attention has been given in a variety of fields to various Indigenous and other non-Western worldviews in terms of their consideration of the capacity of non-human beings to have interests, to manifest their will, and to be considered as an equivalent part of a common and continuous life system. ${ }^{64}$

In Latin American Indigenous worldviews, water has a central role. For example, the Nahua people in México consider water, in all its manifestations, to be a person or agent with intention and capacity to act based on social norms ruled by a logic of cooperation and interdependence. ${ }^{65}$ Likewise, for the Mapuche in Chile and Argentina, water is one of the most powerful expressions of individual and collective equilibrium: when there is transgression in the relationship, the person or community becomes ill. According to the Mapuche worldview, water is in fact, the blood of $\tilde{N} u k e$ Mapu (Mother Earth): we all exist because of it and form part of it. ${ }^{66}$ In the Andean region, Aymara and Atacameña communities have co-evolved culturally and economically since $9000 \mathrm{BCE}$ with ecosystems such as lagoons, salt flats and Andean wetlands. Limited water availability has led these communities to develop complex distribution systems and customary norms for their agricultural activities, which remain mostly intact today. ${ }^{67}$

Leading scholars help provide the potential for legibility, connection and translation of the worldviews of Indigenous peoples in relation to scholarly disciplines and Western-descended legal orders so as to build productive conversations across difference. ${ }^{68}$ These views allow for incorporating notions into normative texts and for judicial decisions of the common good and are supportive of the balance of life view that considers humans to be part of a living whole. ${ }^{69}$

64. Fisher and Lundberg (n 24); Stener Ekern, 'Towards a Mayan Theory of Human Rights: Sacred Equilibria and the Consequences of Disrespect' (2016) 34 Nordic Journal of Human Rights 272; Liliana Galdámez and Salvador Millaleo, 'La Naturaleza en La Constitución: Visiones Indígenas y Propuestas Ante La Crisis' (2020) 26 Acta Bioethic 51; Paola Andrea Acosta Alvarado and Daniel Rivas-Ramírez, 'A Milestone in Environmental and Future Generations' Rights Protection: Recent Legal Developments before the Colombian Supreme Court' (2018) 30 Journal of Environmental Law 519; Ariana Mendoza Fragoso, 'Ontologías Del Agua y Relaciones de Poder En Torno Al Paisaje Hídrico En El Territorio Indígena Mazahua Del Estado de México' (2018) 55 Revista Colombiana de Antropología 91; Erin O’Donnell and others, 'Stop Burying the Lede: The Essential Role of Indigenous Law(s) in Creating Rights of Nature' (2020) 9 Transnational Environmental Law 403.

65. Yuribia Velázquez Galindo and Hugo Rodríguez González, 'El Agua y Sus Significados: Una Aproximación al Mundo de Los Nahuas En México' [2019] Antípoda. Revista de Antropología y Arqueología 69.

66. Biblioteca del Congreso Nacional (BCN), 'El Agua Para Los Mapuche y La Realización de Proyectos Hidroeléctricos En Sus Territorios' (2015).

67. Verónica Grünewald, Ricardo Figueroa and Oscar Parra, 'Recursos Hídricos Asociado a La Actividad Minera En Territorio Aymara', Gobernanza del agua en Latinoamérica y Europa: actores sociales, conflictos y territorialidad (Annablume Editions 2009); Rugerd Boelens, Armando Guevrara-Gil and Aldo Panfichi, 'Indigenous Water Rights in the Andes: Struggles Over Resources and Legitimacy' (2010) 20 Water Law 268.

68. O'Donnell and others (n 64).

69. Craig M Kauffman and Pamela L Martin, 'Can Rights of Nature Make Development More Sustainable? Why Some Ecuadorian Lawsuits Succeed and Others Fail' (2017) 92 World Development $130<$ http://dx.doi.org/10.1016/j.worlddev.2016.11.017>. 
The dominance of scientific knowledge over other knowledges requires examination, but this does not mean that scientific knowledge should be disregarded. Instead, a horizontal dialogue between diverse epistemologies could give way to an 'ecology of knowledges'. ${ }^{70}$ In fact, the integration of different knowledge systems has been identified as a key priority for maintaining biodiversity's contributions to people in Latin America. ${ }^{71}$ Scientific and Indigenous knowledges have different ways of acquiring, making sense of, and communicating knowledge. ${ }^{72}$ Attempts at this kind of knowledge dialogue should avoid naiveté, recognizing that it will not always be possible to peacefully articulate multiple sources of knowledge, or valuations, of Nature.

As a discipline, law has frequently imposed outcomes that are neither technically adequate nor socially pertinent. In this regard, we believe that the role of legal structures, especially at the constitutional level, is to provide on the one hand a legal pluralist approach that illustrates the dynamic interconnections between normative orders $^{73}$ and, on the other hand, mechanisms for conflict resolution when potentially irreconcilable views engage with one another, rather than for silencing diverse ontologies, ${ }^{74}$ or for establishing a priori the dominance of one form of knowledge over another. It is not possible to determine a one-size-fits-all paradigm that recognizes ontological plurality. The concrete applications of a paradigm of rights of Nature will necessarily be unique for each geographical region, each human group, each river and its associated forms of understanding river functioning.

\section{METHODOLOGICAL APPROACH}

The methodology adopted in this article is situated in a debate concerning the theoretical foundations of legal instruments that conceptualize the relationship between humans and Nature. In so addressing this, we aim to weave fluvial geomorphology and ecology with the judicial paradigms that currently operate in Latin America.

Our analysis is grounded in a solid review of this Latin American literature in dialogue with leading global scholarship: considering regional literature constitutes part of the necessary analysis of the case studies selected, and also serves as a way to highlight the breadth and quality of this scholarship as a contribution to broader global debate.

70. Boaventura de Sousa Santos, Para Descolonizar Occidente. Mas Allá Del Pensamiento Abismal (1st edn, Prometeo Libros 2010); Boaventura de Sousa Santos, Descolonizar El Saber, Reinventar El Poder (Ediciones Trilce 2010); Agrawal, 'Indigenous Knowledge and the Politics of Classification' (n 61).

71. Richard Pearson and others, 'Research Priorities for Maintaining Biodiversity's Contributions to People in Latin America' [2019] UCL Open Environment 2.

72. Agrawal, 'Dismantling the Divide Between Indigenous and Scientific Knowledge' (n 61); Natalie C Ban and others, 'Incorporate Indigenous Perspectives for Impactful Research and Effective Management' (2018) 2 Nature Ecology \& Evolution $1680<$ http://dx.doi.org/ 10.1038/s41559-018-0706-0>.

73. Margaret Davies, 'Legal Pluralism' in Peter Cane and Herbert Kritzer (eds), The Oxford Handbook of Empirical Legal Research (Oxford University Press, 2010) 805-27.

74. Julian S Yates, Leila M Harris and Nicole J Wilson, 'Multiple Ontologies of Water: Politics, Conflict and Implications for Governance' (2017) 35 Environment and Planning D: Society and Space 797. 


\subsection{Comparative law approach and interdisciplinary dialogue}

The judicial dimension in this convergence of concerns is addressed here through a jurisprudential analysis of compared case studies, corresponding to three Latin American jurisdictions: Colombia, Ecuador and Chile. The comparison is implemented by examining three emblematic court rulings related to the regulation and administration of rivers. These cases share a regional Latin American context, a similar epoch of jurisdiction, and a similar history of environmental degradation.

The specific cases under consideration constitute landmarks that have reached the highest judicial level of each country, pushing forward the frontier of how the regulation of Nature is conceptualized and operationalized. To illustrate these advances within the regional context, we present a timeline including the current constitutions of Chile, Colombia and Ecuador, as well as the court cases that have dealt with the regulation of rivers in a way that is representative of each of these constitutional paradigms (Figure 1). The selection of individual cases corresponds in Ecuador to the recognition of rights of Nature, specifically rivers as natural entities; in Colombia to legal cases that recognize the rights of rivers; and in Chile to emblematic cases related to water use rights that affect Indigenous and local communities.

The review of court rulings undertaken in this article is complemented by a theoretical analysis of existing constitutional paradigms, which allows us to illustrate the evolution of the construction of Nature as a holder of legal personhood and rights in Latin America.

Comparative law might provide new tools to advance legal diversity. Originally thought of as being a comparison between 'civilized' nations, comparative law, as used in this article, offers a chance to look beyond law's institutional and positivistic framework and to engage with different scientific disciplines and with multiple cultures' world visions in order to influence actions and norms. ${ }^{75}$ Normativity is channeled through human subjects with diverse interpretations and contexts: a pluralist legal approach could provide a necessary 'open' account of law. ${ }^{76}$

The justification for comparing judicial approaches at the constitutional level, in contrast to the civil law level, is sustained by the fact that the constitution is the structural coexistence framework of a country. From a legal perspective, the constitution is the normative body of rules of the highest hierarchical level (in line with international law) and permeates all laws and regulations below it. Emerging Latin American Constitutionalism offers a counter-hegemonic paradigm, which is undoubtedly not easy to implement. Still, it constitutes a contribution strongly nourished by the knowledge of Indigenous peoples and makes way for dialogue with disciplines outside the legal realm. This is well exemplified by section $\mathrm{n}^{\circ} 388$ of the Constitution of Ecuador, which explicitly details the State's responsibility to invest in scientific research and to support the recuperation and development of ancestral knowledge of Indigenous peoples.

Venturing beyond a positivist legal perspective is necessary both for dealing with environmental issues, and for questioning foundational disciplinary concepts such as property, human rights and development. ${ }^{77}$ Considering the interdisciplinary

75. Günter Frankenberg, 'Critical Comparisons: Re-Thinking Comparative Law' in Maksymilian Del Mar, William Twining and Michael Giudice (eds), Legal Theory and the Legal Academy (1st edn, Routledge 2010).

76. Davies (n 73).

77. Usha Natarajan and Kishan Khoday, 'Locating Nature: Making and Unmaking International Law' (2014) 27 Leiden Journal of International Law 573. 


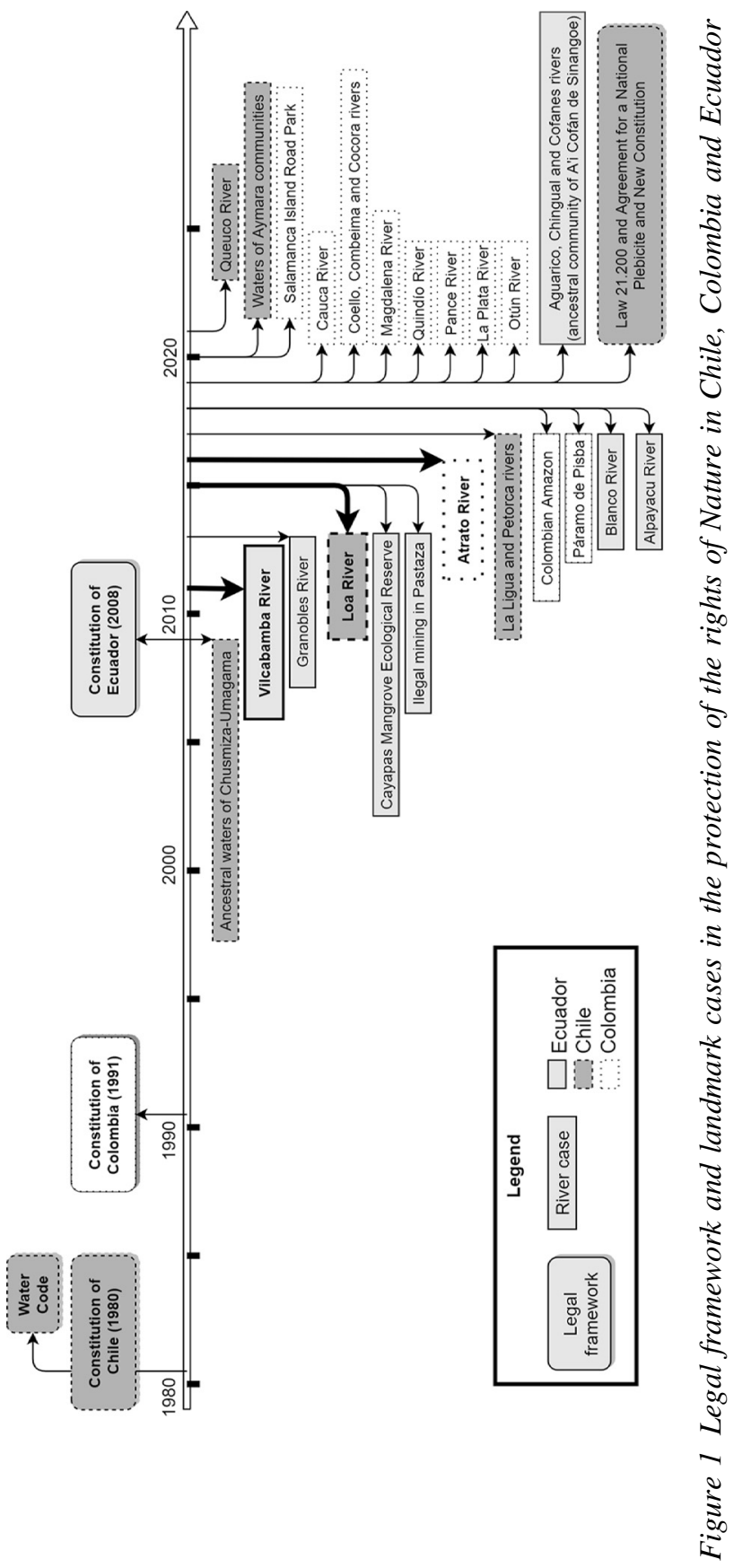


framework required in order to deal with river protection, in all stages of writing we employed an approach and methodology that allowed for the iterative integration of different perspectives. ${ }^{78}$ The combination of views was woven throughout the different stages of research: topic orientation, formulation of the theoretical framework, analysis and discussion of results. ${ }^{79}$ The group of authors held brainstorming sessions and regularly triangulated concepts in order to achieve the integration of contributions from different scholarly cultures (natural sciences, law and social sciences). ${ }^{80}$ The conceptualization of the 'why' and the 'what for' of this study resulted directly from these sessions and were the product of a collective effort to construct a common language.

\subsection{Case studies}

The three case studies selected provide examples of contemporary threats that Latin American rivers face and the current constitutional paradigms that are used to resolve conflicts: the Loa River in Chile (Judgment 118-2014 of Antofagasta Court of Appeals), the Atrato River in Colombia (Judgment T-622-16 of the Constitutional Court) and the Vilcabamba River in Ecuador (Judgment 03-30 of 2011 Provincial Court of Justice of Loja) (Figure 2).

The variable compared is the legal regulation of Nature at the constitutional level. Considering the reasoning and outcome of the cases studied, we evaluate the subsequent well-being of the river and its legal guarantee through the corresponding court rulings. For each case we examine what the judges managed to perceive as a violation of rights, how they evaluated it and how they intended to correct it.

\subsubsection{Loa River: Nature as an object paradigm}

The Loa River is located in the Antofagasta Region of Chile. It follows a U-shaped trajectory for about $440 \mathrm{~km}$, from the High Andean Plateau to the Pacific Ocean. The riverscape - composed of the main river channel, a couple of small tributaries and seasonal streams - is a very dry one as it forms part of the Atacama Desert. At the headwaters, where this case study takes place, the mean temperature is $15^{\circ} \mathrm{C}$ and annual precipitation is about $250 \mathrm{~mm}$, concentrated in the summer months between December and February. ${ }^{81}$ The Loa basin has a severe water deficit due to the high demand for agriculture, mining and human consumption - as has been reported by the Regional Government of Antofagasta. ${ }^{82}$ In spite of the river being considered

78. Arnout RH Fischer, Hilde Tobi and Amber Ronteltap, 'When Natural Met Social: A Review of Collaboration between the Natural and Social Sciences' (2011) 36 Interdisciplinary Science Reviews 341.

79. Steph Menken and Machiel Keestra (eds), An Introduction to Interdisciplinary Research: Theory and Practice (Amsterdam University Press 2016).

80. Hilde Tobi and Jarl K Kampen, 'Research Design: The Methodology for Interdisciplinary Research Framework' (2018) 52 Quality and Quantity 1209.

81. Biblioteca del Congreso Nacional, 'Clima y vegetación Región de Atacama' (2020) $<\mathrm{https}: / /$ www.bcn.cl/siit/nuestropais/region3/clima.htm>.

82. Centro de Ecología Aplicada, 'Informe Final. Diagnóstico Del Caudal Ambiental Del Río Loa, Región de Antofagasta' (2020). 

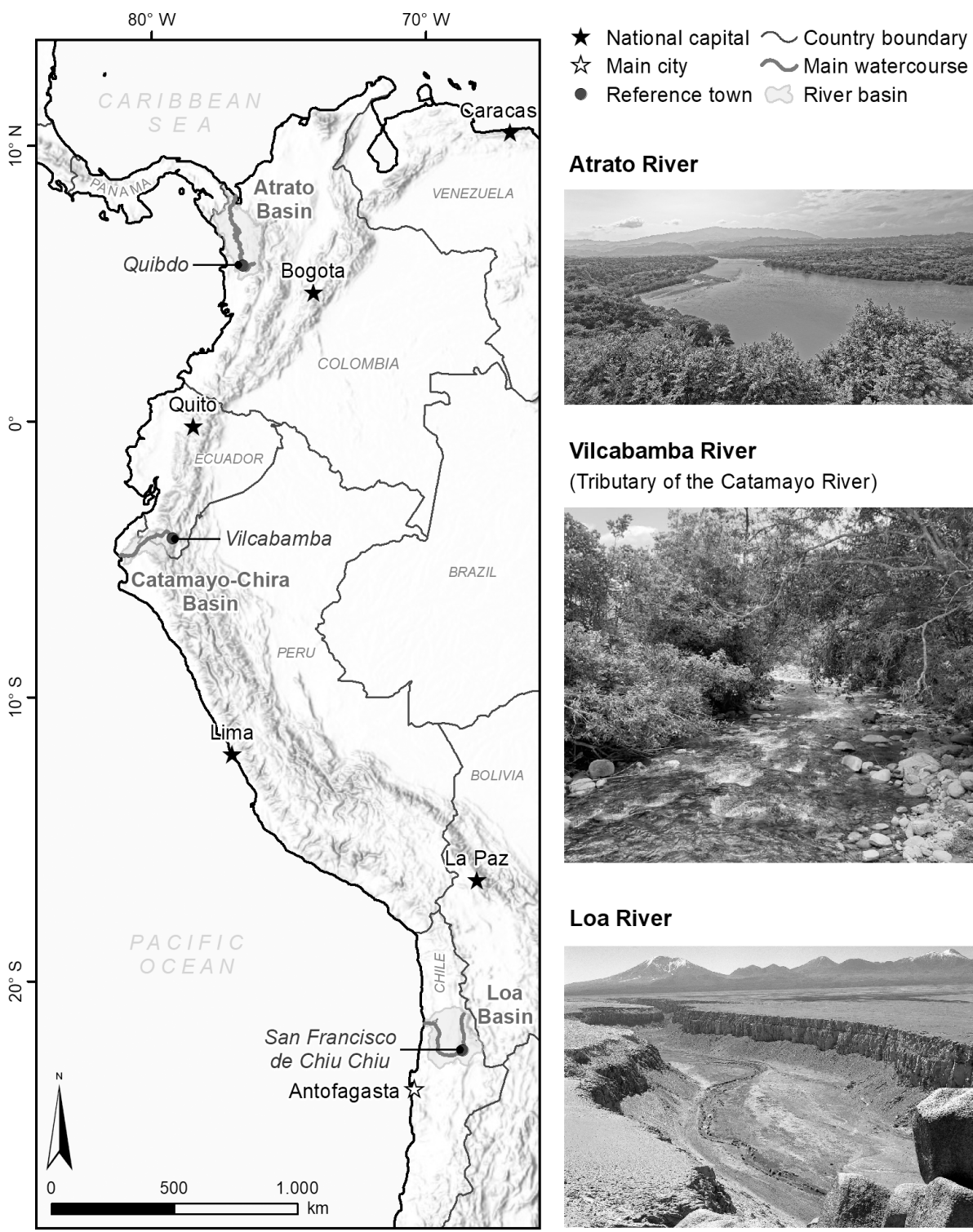

\section{Atrato River}

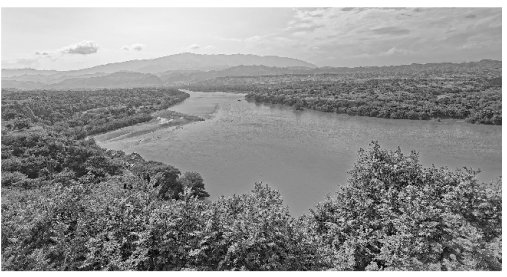

Vilcabamba River

(Tributary of the Catamayo River)

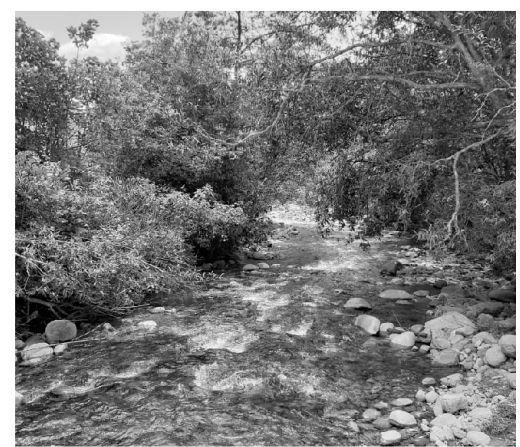

\section{Loa River}

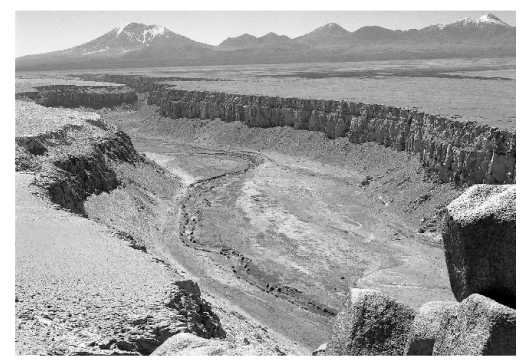

Source: Camila Bañales-Seguel. Photo credits: first and third photos are open source, second photo is from Felipe Morejón.

Figure 2 Location of each basin and representative photos of their corresponding landscapes

an exhausted (in fact, over-exploited) water source, the government has no constitutional responsibility to provide a more comprehensive solution to this river's situation.

The river and its surroundings are part of an Indigenous Development Area (ADI), an administrative State denomination established in the country's Indigenous 
Law ( $\left.\mathrm{n}^{\circ} 19.253\right)$ used to indicate the presence of Indigenous communities and their close relationship with the territory which is considered a 'habitat'. Habitat refers to lands that Indigenous communities have ancestrally inhabited (Section 13.2 ILO 169 Convention) where they have developed a cultural and ecological dependence on the natural assets of these territories. This relationship can be seen through practices in relation to and uses of river basins, rivers, riparian areas, flora and fauna.

The Atacameña Indigenous community, who live in the town of San Francisco de Chiu Chiu (located at 2525 meters above sea level in the headwaters of the river), has used waters from the Loa River for centuries. However, the Chilean legislation demands regularization - a complex legal process to recognize ownership - of these customary water rights. Regularization requires providing proof of a minimum of five years of use, free of clandestine extraction or violence, and proof that there are no third-party claims or ownership (Art $2^{\circ}$ Chilean Water Code). ${ }^{83}$

Chile is an emblematic example of the 'water market' model for the allocation of water rights with little or no State regulation. ${ }^{84}$ This model has four decades of momentum behind it, since the 1980 Constitution (which put private property at the center of the frame) and its formal establishment through the 1981 Water Code legal bodies both established amidst a military dictatorship. The consequences of this model have resulted in the over-extraction of both surface and underground sources of water ${ }^{85}$ as well as profound legal, social and ecological impacts documented throughout the country. ${ }^{86}$ In the region where the Loa River is located, significant water conflicts have arisen linked to mining activities on the lands of Indigenous peoples. $^{87}$

The judicialization of this case began in 2007 when Salvador Mamami, a member of the Atacameña community, requested that the General Water Directorate (DGA by

83. Código de Aguas 1981.

84. Fernando Ochoa and others, 'El Acceso al Recurso Hídrico en La Praxis Judicial Chilena: Paradojas y Malas Prácticas' (2016) 6 Actas de Jornadas de Derecho de Aguas 5; Budds (n 15); Bauer (n 52); Amaya Álvez, 'Constitutional Challenges of the South: Indigenous Water Rights in Chile - Another Step in the "Civilizing Mission"?' (2017) 33 Windsor Yearbook of Access to Justice $87<$ <ttps://ojs.uwindsor.ca/ojs/leddy/index.php/WYAJ/article/view/4888>.

85. Anahí Urquiza and Marco Billi, 'Water Markets and Social-Ecological Resilience to Water Stress in the Context of Climate Change: An Analysis of the Limarí Basin, Chile' (2020) 22 Environment, Development and Sustainability 1929; Verónica Delgado Schneider, 'Reparación del Daño Ambiental Causado a Las Aguas Subterráneas en Los Tribunales de Chile' [2019] Revista de Derecho Privado 279; Iongel Duran-Llacer and others, 'Lessons to Be Learned: Groundwater Depletion in Chile's Ligua and Petorca Watersheds through an Interdisciplinary Approach' (2020) 12 Water (Switzerland).

86. Sara Larraín and Pamela Poo, Conflictos Por El Agua En Chile. Entre Los Derchos Humanos y Las Reglas del Mercado (Gráfica Andes 2010); Sara Larraín, 'El Agua en Chile: Entre Los Derechos Humanos y Las Reglas del Mercado' [2006] Polis. Revista Latinoamericana; Nancy Yáñez, 'Los Problemas Equidad Social y Ambiental del Modelo Chileno de Aguas Desde La Perspectiva de Los Derechos Fundamentales', Seminario en Latinoamérica de Teoría Constitucional y Política (2016); Roberto Costumero and others, 'Geography of Legal Water Disputes in Chile' (2017) 13 Journal of Maps 7; Raphael Cantillana, 'Los Estudios del Agua en Chile: Revisión y Perspectivas Críticas' (2020) 11 Tecnología y Ciencias del Agua 61; Ariel A Muñoz and others, 'Water Crisis in Petorca Basin, Chile: The Combined Effects of a Mega-Drought and Water Management' (2020) 12 Water (Switzerland).

87. Francisco Molina Camacho, 'Intergenerational Dynamics and Local Development: Mining and the Indigenous Community in Chiu Chiu, El Loa Province, Northern Chile' (2016) 75 Geoforum 115 <http://dx.doi.org/10.1016/j.geoforum.2016.06.015>. 
its Spanish initials) should regularize the community's water rights consisting of $1.1 \mathrm{~L} / \mathrm{s}$ obtained from the Loa River. The request was rejected because the Loa River had, since January 2000, been declared exhausted on the basis of water scarcity. According to the Water Code (section 282), this meant that no new water rights could be constituted. The legal discussion was centered upon whether this rejection from the DGA was in accordance with the country's legal framework.

The Antofagasta Court of Appeals (Judgment 118-2014 of Antofagasta Court of Appeals) interpreted the argument for the rejection of the community's request as being flawed because the request was not to constitute new water rights, but rather to grant legal recognition of pre-existing customary water rights. These rights were validated on the basis of customary use of the Atacameña community. In this sense, section 282 yielded to transitory section 2, which empowers the DGA to regularize water rights to those who are using them.

To support this determination, the Court considered a report from the National Corporation for Indigenous Development (CONADI). This report indicated that the Loa River corresponds to an area that supports unique and fragile ecosystems, endemic to the Altiplano, and which are also the ancestral habitat of the Atacameño and Aymara Indigenous peoples. These communities develop agricultural and livestock activities, making rational use of the available water and land by alternating the occupation of complementary ecological units, a practice known as transhumance. ${ }^{88}$ The recognition of the cultural importance of Indigenous peoples includes their legal customs, and the report from CONADI recounts the community's customary use of the river for at least 50 years, providing evidence that complies with the norm. Thus, the water rights requested correspond to customary uses of the Atacameña community represented by Mr Mamami.

However these uses were forced to be regularized under Chilean laws. The Water Code allows the recognition of 'ancestral water rights' to be open to any user and for any purpose (including extractivism). The model of private water rights without prioritization creates a false concept of ancestral water rights, which puts them in competition with extractive mining uses ${ }^{89}$ and perpetuates the neutralization of their claims. ${ }^{90}$ Even though the Court recognized customary use and declared that Mr Mamami is owner of the water rights requested from the Loa River, the case is a clear example of the paradigm of Nature as an object of law. What seems to be an advancement the recognition of customary water uses of the Aymara community - serves only as proof of the regularization of a private right to use Nature according to the norms of the Water Code. The judicial discussion was limited to the question of the ownership of the water rights and therefore to the water source itself, without considering the hydrological reality of the river and the interruption of its ecological functions. In short, the court ruling consolidated cultural domination through the imposition of the Water Code over the logic of Aymara customary rights. It recognized water rights, but only to the extent that they fit within the Water Code, and not in accordance with the conception of ancestral waters as has been established in international treaties that recognize Indigenous peoples as subjects of law.

88. ibid.

89. Ochoa and others (n 84).

90. Amaya Álvez and others, 'Waters of Andean Indigenous Peoples - Ancestral Rights and the Neutralization of their Claims' in Diego Rivera, Alex Godoy-Faundez and Mario Lillo-Saavedra (eds), Andean Hydrology (Taylor \& Francis Group 2018). 


\subsubsection{Atrato River: biocultural rights paradigm (hybrid system)}

The Atrato River is located in the Chocó Department of Colombia, whose capital is the town of Quibdo. The river is born in the northern end of the Andes, and flows north $750 \mathrm{~km}$, gathering waters from 150 tributaries, until pouring into the Gulf of Urabá in the Caribbean Sea. The climate in this region is influenced by the Intertropical Zone of Confluence and produces one of the rainiest parts of the globe, reaching up to 10 meters of rainfall a year in some areas, with a mean annual temperature of $28^{\circ} \mathrm{C} .{ }^{91}$ This makes the Atrato one of the rivers with the greatest discharge in the world, with up to $1022 \mathrm{~m}^{3} / \mathrm{s}^{92}$ The riverscape is characterized by broad valleys with frequently inundated floodplains. ${ }^{93}$ Given the dense vegetation in this region, rivers were the route chosen by the Europeans for exploring the continent.

Since the end of the 1990s, the high and middle basins of the river have been subjected to large-scale mining, both legal and illegal. This activity has brought about consequences such as the destruction of the river bed, and the discharge of mercury and other water and air pollutants resulting from the treatment of chemicals in the mining sites.

Indigenous peoples and afro-descendants (further referred to as ethnic groups in this case study) who inhabit the river basin filed a guardianship action requesting the protection of fundamental rights to life, to health, to food safety, to a healthy environment, to culture, and to the territory of their communities. The Colombian Constitutional Court (Judgment T-622-16 of the Constitutional Court) recognized the biocultural rights of the ethnic communities and of Nature and centered the interpretation of these rights on the superior interest in protecting the environment for future generations. This interpretation was broadly developed in the Court through the application of numerous constitutional clauses that form what is often denominated as the 'Ecological Constitution' or 'Green Constitution'. The Court considered that it needed to step forward in the constitutional protection of the Atrato River and its tributaries, and to do that it was necessary to adopt an integral approach to conservation that recognizes the relationship between biological and cultural diversities. The application of the concept of biocultural rights, which comes from an ecocentric perspective, implies considering humans to be part of Nature, not as a domineering agent. This concept entails that policies, norms and interpretation of biodiversity conservation should recognize the interrelation that exists between culture and Nature. This would mean extending the participation of human communities in the definition of public policies and regulatory frameworks and guaranteeing the conditions for the generation, conservation and renewal of their knowledge systems.

The Court's ruling marked two landmark points. First, the Court's recognition of biocultural rights highlighted the direct connection between the protection of rivers,

91. IIAP (Instituto de Investigaciones Ambientales del Pacífico), 'Análisis y Propuesta SocioEconómica y Cultural Para El Canal Navegable Del Río Atrato' (2016) <http://rioatrato.org/sites/ default/files/ANA\%CC\%81LISIS\%20SOCIOECONO\%CC\%81MICO $\% 20$ Y\%20CULTURAL\% 20DEL\%20CANAL\%20NAVEGABLE\%20DEL\%20RI\%CC\%810\%20ATRATO\%20copia. pdf> accessed 8 October 2020.

92. Osso-UNDP, '8. Información Hidrometeorológica' (Informe Final Estructura Ecológica Principal Chocó Biogeográfico. Proyecto PNUD COL/95/009/010, 1998) <https://www.osso. org.co/docu/proyectos/grupo-osso/1998/atrato/informacion.pdf> accessed 8 October 2020.

93. IIAP (Instituto de Investigaciones Ambientales del Pacífico), 'Estudio Técnico Para La Designación Del Nuevo Sitio Ramsar Complejo Cenagoso Del Bajo Atrato, Chocó - Colombia' (2018). 
forests, food sources and biodiversity and the human rights to life and health. Therefore, the conservation of biodiversity implies the preservation of the lifestyles and cultures that interact with it. The second point had to do with the pollution of the Atrato River, along with its tributaries, forests and food sources, as an impact of mining activities, which, according to the Court, contradicts the idea of a rational use of aquatic and terrestrial living systems. The polluting impact on the Atrato River hinders the possibility of present and future human generations sustaining balanced relations with the environment, a widely accepted premise of sustainability. It also impacts the human right to water, which is considered to be a requirement sine qua non for the exercise of other human rights.

This logic guided the Court's decision to declare the Atrato River to be a subject with legal personhood and with rights that have to do with its protection, conservation and restoration. To achieve the fulfillment of these rights, the Court determined that the State should exercise legal guardianship and representation of the Atrato River. The State representatives, together with local ethnic groups, had to design and form a Commission of Guardians of the Atrato River. On 26 July 2018, the first session of the Commission of Guardians of the Atrato River was held. The Ministry of the Environment provided an evaluation of the level of fulfillment of the ruling, specifically of the decontamination plan. This plan has three phases and is oriented by five lines of work: territorial planning and ordering; environmental quality improvement; sustainable production; environmental governance; and knowledge and information management.

Along with the decontamination plan, multiple other programs, projects, contracts and agreements were developed to achieve the measures for restoring the impacted zones of the Atrato River and of the Chocó department. For example, the Ministry of Defense created a plan to eradicate the illegal extraction of minerals, the Ministry of Health is in charge of epidemiological and toxicological studies, and the Ministry of Agriculture designed a food security plan. Finally, an Intersectoral Commission for the Chocó was created, whose goal is to hold the Chocó department accountable and to guarantee that its actions are aligned with the determinations of all the ministries involved.

Once the mining activities were suspended in Quito River, a tributary of the Atrato, the deforestation in the Chocó and in the Atrato River basin was reduced. The second phase of the decontamination plan started in August 2019, and consisted of workshops with the ethnic groups of Chocó and Antioquia. ${ }^{94}$ These workshops were oriented towards constructing a collective and democratic Action Plan for the decontamination and restoration of the river channel, the elimination of mercury pollution, the reforestation of affected areas, and the promotion of green entrepreneurs in the region.

The Atrato case stands out by granting legal personhood to a natural entity by operation of Court jurisprudence (and not by constitutional or legal consecration). ${ }^{95}$ The novelty of this paradigm cannot be understood, however, without the consideration and development of biocultural rights, which are based on Colombian constitutional and legal bases. These rights oblige the authorities to incorporate Indigenous peoples and afro-descendants in legal participation, with full respect for their

94. Cagüeñas, Orrego and Rasmussen (n 35).

95. Cano Pecharroman (n 10); Liliana Estupiñan Achury, 'Neoconstitucionalismo Ambiental y Derechos de La Naturaleza en El Marco del Nuevo Constitucionalismo Latinoamericano. El Caso de Colombia' in Liliana Estupiñan Achury and others (eds), La Naturaleza como sujeto de derechos en el constitucionalismo democrático (Universidad Libre 2019). 
collective and territorial rights, in addition to giving them an active role in the management of the river, a role that includes their traditional knowledge as guardians. ${ }^{96}$

Such an unprecedented concept is followed by other cases in Colombia (see the timeline in Figure 1), serving as a source for other courts to adopt the same decision regarding the recognition of the legal personhood of rivers and natural entities. However, the judgment did not contain a clear indication or method to determine when legal personhood must be conceded to rivers or other natural entities. This assessment is left to be conducted on a case-by-case basis, resulting in an inadequate consideration of biocultural rights by not recognizing the interests of local communities in land and water management. ${ }^{97}$

Finally, the main obstacle in the operationalization of rights of Nature (specifically the rights of rivers in Colombia) is the lack of willingness on the part of State authorities and institutions to make public resources available for developing and complying with environmental goals and plans.

\subsubsection{Vilcabamba River: rights of Nature paradigm}

The Vilcabamba River, located in the Loja Province of Ecuador, is an Andean tributary of the bi-national basin of the Catamayo-Chira River. This basin is shared between Ecuador and Perú and its waters flow into the Pacific Ocean. The riverscape of the Vilcabamba River has a mean elevation of 1552 meters above sea level and enjoys a privileged subtropical-dry climate, with an average temperature of $19^{\circ} \mathrm{C}$ and a rainy season between October and May with an annual mean rainfall of $770 \mathrm{~mm} .{ }^{98}$ The etymology of the river's name comes from Quechua Indigenous language; 'willka', meaning sacred or divine, and 'pampa' meaning pasture, plain or open field. ${ }^{99}$ These 'sacred plains' are believed to have been a place of rest for the Incas in their travels through the Andes.

The Vilcabamba River was impacted by the widening of a highway linking the towns of Vilcabamba and Quinar. Between 2009 and 2010 the Provincial Government of Loja deposited stones and other excavation material into the river. During the rainy season, when the river's flow increased considerably, it swept away thousands of tons of construction waste, causing flooding and direct damage to surrounding properties. The owners of riverside property issued a protective order for the violation of the rights of the Vilcabamba River against the State Attorney's General Office in Loja.

Faced with the novelty of the discourse on the rights of Nature, the Provincial Court of Justice of Loja (Judgment 03-30 of 2011 Provincial Court of Justice of Loja), managed to put in motion Article 71 of the 2008 Constitution of Ecuador which requires that any time someone claims recognition of the rights of Nature through a public action, the Court must directly apply the normative framework established in the Constitution.

96. Elizabeth MacPherson, Julia Torres Ventura and Felipe Clavijo Ospina, 'Constitutional Law, Ecosystems, and Indigenous Peoples in Colombia: Biocultural Rights and Legal Subjects' (2020) 9 Transnational Environmental Law 521.

97. ibid.

98. Gobierno de Loja, 'San Pedro de Vilcabamba' (Loja para todos, 2020).

99. Rodolfo Cerrón-Palomino, Quechua Sureño: Diccionario Unificado, Quechua-Castellano, Castellano-Quechua (Biblioteca Nacional del Perú 1994). 
The Court established, as a guideline, that all damage to Nature constitutes 'intergenerational damage', which, due to its magnitude, affects not only the current but also future generations. ${ }^{100}$ In the event that there is conflict between public interest and the rights of Nature, such conflict must be resolved in the light of the constitutional principles and values and the specific judicial elements of the case. The Court highlighted that the interest in a healthy environment will always encompass a greater number of people than those directly affected in the moment. ${ }^{101}$

Another aspect to be highlighted is the reversal of the burden of proof contained in Article 397 of the Political Constitution of Ecuador, which indicates that it is the responsibility of the offender to present proof that there was no actual damage. In this case, it was up to the Provincial Government to prove that no damage existed. However, the Provincial Government did not comply with the legal obligation to protect the environment in the first place, as it did not carry out an environmental impact study, and nor did it have an environmental license or permit to carry out the works, much less to discard material from construction that would damage the river. The Court declared that the constitutional rights of Nature were violated and found that Nature's existence and integrity must be respected, as should the maintenance and regeneration of her vital cycles, structure, functions and evolutionary processes. The ruling ordered the Provincial Government of Loja to comply with a set of recommendations established by the Undersecretary of Environmental Quality, through office letter $\mathrm{N}^{\mathrm{o}} 2010-1727$.

These recommendations were initially not followed, so an action of non-compliance was filed before the Ecuadorian Constitutional Court to further pressure the Provincial Government. This action was rejected in 2018. ${ }^{102}$ The Provincial Government published an official letter dated 11 April 2012, in which the Loja Provincial Environmental Directorate approved the 'Environmental Remediation Plan via Vilcabamba and others', which contained measures such as the rehabilitation and remediation of the riparian ecosystem, fencing and signaling to avoid disposal of debris, removal of debris from the river channel, and the revegetation of the riparian corridor, among other actions. Finally, during 2013, the local authority obtained approval of the expost Environmental Impact Assessment. ${ }^{103}$

\section{DISCUSSION}

In recent years there have been notable divergences in the legal regulation of Nature at the constitutional level in Latin America. Chile has deepened a neoliberal stance that

100. Acosta (n 6); Alicia Morales, 'Derechos de La Naturaleza y Justicia Ecológica Intergeneracional' [2019] Prometeica - Revista de Filosofía y Ciencias 13.

101. Richard Fredrick Wheeler, Eleanor Geer Huddle vs el Gobierno Provincial de Loja: Corte Provincial de Justicia de Loja, 'Twelfth Considering of the Appealed Ruling (Richard Fredrick Wheeler, Eleanor Geer Huddle vs El Gobierno Provincial de Loja. No 03-30 of 2011'. 102. Richard Fredrick Wheeler, Eleanor Geer Huddle v el Gobierno Provincial de Loja: Corte Constitucional del Ecuador, 'Richard Fredick Wheeler, Eleanor Geer Huddle vs El Gobierno Provincial de Loja. No 02-2018-SIS-CC' (2018).

103. Richard Fredrick Wheeler, Eleanor Geer Huddle vs el Gobierno Provincial de Loja: Corte Constitucional del Ecuador, 'Richard Fredrick Wheeler, Eleanor Geer Huddle vs El Gobierno Provincial de Loja (2018) 1 AEIA (Approved Environmental Impact Assessment) 21 (CCE) 2 PRA (Environmental Remediation Plan) 259, 3 CPRA (Fulfillment of Environmental Remediation Plan) (CCE)' (2018). 
limits Indigenous rights and treats Nature as a commodity. On the other hand, Colombia has opened itself to judicial interpretations that create a hybrid category of rights that includes elements of Nature represented by Indigenous people and afro-descendent groups. Finally, the people of Ecuador have taken a turn in their constitutional conception by incorporating Nature as a subject, drawing on Indigenous ancestral knowledge as a foundational source.

In the argumentation of some of these Latin American courts' decisions, autochthonous cultural, religious and philosophical elements of the countries in which they have been presented have had great relevance. It has also been pointed out that these arguments are reconcilable with a broader application of emerging constitutional paradigms, which can provide answers to some of the problems posed by the Anthropocene. ${ }^{104}$ Thus, the attribution of rights to rivers in jurisprudence could have a 'normative surplus' that allows the application of the same reasoning and protection measures to other cultural or legal contexts as a strategy to face global threats to Nature. ${ }^{105}$ Moreover, the need to radically depart from existing legal tenets and to incorporate diverse understandings of Nature has been identified as key for overcoming environmentally unsuitable paradigms and evolving towards new formulations. ${ }^{106}$

\subsection{Latin America, for once, is ahead of the game}

Latin America has been a peripheral space that has struggled to emancipate itself from a colonial regime since the nineteenth century. The constitutions and legal regimes of the various Latin American countries facilitated the establishment of a hegemonic Eurocentric culture that subdued the Indigenous peoples of the region. ${ }^{107}$ The Eurocentric concept of Nature was imposed against Indigenous worldviews, as a binary and excluding concept in relation to humans, which are considered to be superior, both morally and philosophically. ${ }^{108}$

This anthropocentric framing has been contested by the recent constitutions emerging from Latin America, especially by the Constitutions of Ecuador in 2008 and Bolivia in 2009. This turn has been achieved through the introduction of guiding principles for the constitutional system such as Buen Vivir (Good Living), which underlines the need for life that is compatible and symbiotic with the environment. ${ }^{109}$ This

104. Francisco Araos and others, 'La Vida Después de La Devastación: Lo Común de La Tragedia En Territorios Sociobiodiversos de Chile y Brasil' (2019) 6 Antropologías del Sur 87; Allison Katherine Athens, 'An Indivisible and Living Whole: Do We Value Nature Enough to Grant It Personhood?' (2018) 45 Ecology Law Quarterly 187.

105. Stefan Knauß, 'Conceptualizing Human Stewardship in the Anthropocene: The Rights of Nature in Ecuador, New Zealand and India' (2018) 31 Journal of Agricultural and Environmental Ethics 703.

106. Natarajan and Khoday (n 77).

107. Bartolomé Clavero, 'Tribunal Constitucional en Estado Plurinacional: El Reto Constituyente de Bolivia' (2012) 32 Revista Española de Derecho Constitucional 29.

108. Avila (n 8).

109. Johannes Waldmueller and Laura Rodríguez, 'Buen Vivir and the Rights of Nature. Alternative Visions of Development' in Jan Drydyk and Lori Keleher (eds), Routledge Handbook of Development Ethics (Routledge 2019); Gudynas, 'Buen Vivir: Today's Tomorrow' (n 8); Alberto Acosta and Mateo Martínez Abarca, 'Buen Vivir: An Alternative Perspective from the Peoples of the Global South to the Crisis of Capitalist Modernty' in Vishwas Satgar (ed), The Climate Crisis (Wits University Press 2018) <https://www.jstor.org/stable/ $10.18772 / 22018010558.5>$. 
supposes, first, a renewed understanding of the clause concerning equality between cultures that inhabit a State and of intergenerational justice. ${ }^{110}$ Secondly, an important question to ask is whether or not the consideration of Nature as the holder of fundamental rights reveals an intrinsic valuation of Nature, overcoming previous instrumentalist treatments. The Political Constitution of Colombia of 1991 does not explicitly consecrate rights of Nature or Nature as a bearer of legal personhood, however there are some explicit principles and diverse rights in environmental law that have allowed the actual construction of this understanding. ${ }^{111}$ In Colombia, the Constitutional Court, through its judicial rulings, has been able to implement a progressive interpretation of the Constitution in order to incorporate biocultural rights. This development has even led to debate on reform of the 1991 Constitutional text.

These recent legal experiences, which have consolidated the 'New' Latin American Constitutionalism, ${ }^{112}$ have been called part of a 'Constituent Spring' in Latin America. ${ }^{113}$ This new season has brought along a novel way of framing the relationship between humans and Nature, pushing for social and environmental change through a regionally authentic source of legitimacy. These new constitutional architectures invite us to imagine new possible worlds ${ }^{114}$ and may well enhance solutions to contemporary challenges. These architectures also constitute a unique expression of the political demands of forgotten majorities such as Indigenous peoples, women and afro-descendants.

\subsection{Comparative analysis of the judicial cases}

In the case of Ecuador, there is a direct application of constitutional norms, and the source of rights is in the Constitution. In the case of Colombia, there is an evolutionary interpretation of the Constitutional text that leads judges to recognize the rights of rivers and biocultural rights, as well as the human rights to water, to a healthy environment and to food security. The sources of these rights lie in ecocentric environmental ethics and in the obligations of the State. In the Chilean case, the discussion is limited to regulatory norms and laws, which are juridically inferior to constitutional norms. This is because, at the constitutional level, Nature is considered to be an object: at the center of the debate is the ownership of a right of use by a natural or legal person, which is protected by private property rights. Currently Chile is undergoing a constituent process, which is the product of explosive social protest that began in October 2019 and obliged the government to respond to citizens' demands for a New Constitution. Although the outcome of this process is uncertain, the exacerbation of social-ecological conflicts has generated strong citizen demand for the protection of Nature. The human right to water, and the rights of Indigenous peoples, have been at the center of many debates. ${ }^{115}$

The incorporation of autonomous rights of Nature (Ecuador, and partially Colombia) implies an epistemological turn in the traditional constitutional doctrines in several ways. First, it means accepting that law and rights do not only come from a State source and that they are a cultural product. Second, it means that the discipline and

110. Morales (n 100).

111. Estupiñan Achury (n 95).

112. Wolkmer, Wolkmer and Ferrazzo (n 29); Medici (n 7).

113. Martha Zaldívar, 'Primavera Constituyente Entre Viejos Demonios: Un Nuevo Despertar Para América Latina' (2011) 27 Revista del Instituto de Ciencias Jurídicas de Puebla 295.

114. Martínez and Acosta (n 29).

115. Domingo Namuncura and others, Wallmapu. Ensayos Sobre Plurinacionalidad y Nueva Constitución (Pehuén 2020); Galdámez and Millaleo (n 64). 
practitioners of law must open up to work and to dialogue with other disciplines (for example, river science) and draw upon knowledge sources (for example, local, traditional, Indigenous), and accept that to resolve judicial cases, judges must incorporate technical aspects through extrinsic evidence.

With respect to the constitutional stature of water, in the case of Ecuador and Colombia, priority uses are recognized in their legislation, and the courts recognize that water has intrinsic value within the ecosystem and for local communities. Ancestral customary uses are recognized for Indigenous peoples and afro-descendant groups, based around their lifestyles and traditional customs. In the case of Chile, the recognition of the rights to water for Indigenous peoples is mediated by the logic of private property ownership and therefore is not comparable to recognition.

The structure and focus of the legal personhood involved in each case also has practical implications for the constitutional rights invoked. In the Ecuadorian and Colombian cases, legal personhood is attributed to the river itself. Not so in the Chilean case, where only the extractive 'user' of the water has legal personhood (and the Indigenous user only insofar as they are extractive users). It is paramount to apply the theory of legal representation, especially in cases where Nature is the holder of the fundamental right. The active plaintiffs in the cases of Ecuador and Colombia are social organizations (a kind of citizen action in the case of Ecuador, and Indigenous communities in the case of Colombia). In the Chilean case, the ownership of fundamental rights is restricted to natural or legal persons: here Mr Mamami, who is a natural person belonging to an Indigenous community and who is represented by the National Indigenous Agency (CONADI). In this case, representation is contrary to international law since the rights of Indigenous peoples are considered to be collective and not individual.

The person obliged to respect, protect and guarantee the fundamental rights affected, denominated the passive plaintiff, is in all cases a State agency.

All three cases share a context of economic development and extractivism. In all three cases, the source of the rights violations in question is connected with, and motivated by, extractivism. The Ecuadorian and Chilean cases differ in that the cause of rights violations is driven by the projects of private companies with State support, while in the Colombian case, the cause is small and medium-sized illegal miners, who work in the context of the armed conflict in that country. The agents that produce disturbance in the ecosystem or prevent access to water for other uses are, respectively: in the Vilcabamba River case, the road construction company; small illegal mining in the case of the Atrato River and large mining and sanitary companies in the Loa River. The impacts on these rivers are related to the alteration and contamination of the river channel (Vilcabamba and Atrato Rivers). Meanwhile, in the Loa River the impact is directly related to the extraction of water, although it also occurs in a context of water contamination. ${ }^{116}$

The results of the judicial cases, also called their 'normative surplus' ${ }^{117}$ specifically the Vilcabamba and Atrato cases, generate normative criteria in favour of Nature and applicable in similar cases. In the Chilean case, a regulatory surplus is scarce: the main contribution of the case is to reaffirm the recognition of water use rights to ancestral users. In the Colombian case, a follow-up commission was created, made up of representatives of the State and of members of the communities as a 'commission of guardians', who must report to the court on the progress of compliance.

116. Centro de Ecología Aplicada (n 82).

117. Knauß (n 105). 
In Ecuador, the monitoring mandated by the court ruling is assigned to a public body, and there is a course of action to address non-compliance before the Constitutional Court. In Chile, however, there is no follow-up.

Another relevant element to consider is that the Ecuadorian and Colombian cases incorporate elements of intergenerational justice in their decision. In the Chilean case, the problem is reduced to the distributive and procedural justice of the administrative authority. Stefan Knau ${ }^{118}$ highlights the possibility provided by the Ecuadorian constitutional text of challenging the limits of the discussion before the courts, a possibility expressed both in the nature of the action taken in the case of the Vilcabamba River, and in the social mobilization and environmental protection agenda promoted by citizens in the case.

\subsection{Alignment of judicial rulings with parameters of river well-being}

Based on the case studies investigated and the legal paradigms they represent, there is a divergence between natural parameters of well-being as seen from the perspective of disciplines that study rivers and what has been included in the judicial rulings. In the end, if the legal paradigm, with its epistemological background, is not changed, there is a small margin for the production of different practical outcomes, for how natural entities are legislated, and for how legislation is applied. The change required must necessarily include the opening of judges and courts to influences beyond their disciplinary specialization. ${ }^{119}$

Rivers as natural entities present multiple alternatives for the operationalization of the paradigm of rights of Nature, as has been exposed through the Loa, Atrato and Vilcabamba cases. Our findings affirm that the contribution of disciplines such as ecology, hydrology and fluvial geomorphology, as well as local and Indigenous knowledge, must be translated into the legal language employed by judges and courts. Specifically, these scientific and non-scientific views should inform the delineation of river rights by answering some challenging questions: ${ }^{120}$ How do we define the natural entity (rivers)? What are the rights to be protected and what should be monitored? Who should defend these rights or ensure that they are respected?

There are already important advances towards the operationalization of river rights. From a fluvial geomorphology perspective, supported by dialogue with Indigenous populations in New Zealand, Brierley et al. ${ }^{121}$ propose seven rights of rivers that should be recognized. Their proposal articulates several biophysical attributes that can be used to support geomorphological 'rights' of rivers. The authors consider initiatives adopted in different countries that promote notions such as 'space to move' or 'freedom space' for rivers. ${ }^{122}$ Since fluvial geomorphology is concerned with the processes that shape rivers and their relationship with landscape, ${ }^{123}$ this proposal places an emphasis on physical dynamics. For example, the natural variability in

118. ibid.

119. Natarajan and Khoday (n 77); Knauß (n 105).

120. Chapron, Epstein and Lopez-Bao (n 33).

121. Gary Brierley and others, "A Geomorphic Perspective on the Rights of the River in Aotearoa New Zealand' [2018] River Research and Applications 1.

122. Buffin-Bélanger and others (n 56).

123. Wohl (n 49). 
the hydrological regime ${ }^{124}$ is translated into the 'right to flowing water', and the importance of sediment transport ${ }^{125}$ is translated into the 'right to convey sediment ${ }^{126}$ as a requirement for the natural equilibrium between processes of sediment erosion, transport and deposition. The natural dynamics of river adjustment and evolution are also recognized as part of the catalogue of river rights. ${ }^{127}$

Another proposal is the Grant Wilson Universal Declaration of River Rights. ${ }^{128}$ This Declaration offers guidelines that aim to serve as a blueprint for governments to develop legislation that recognizes river rights within their particular jurisdictions. By urging that countries should adapt these guidelines into their domestic laws and recognize a similar set of rights of rivers, this declaration intends to establish customary international law for river rights. The first of the six rights contained in Article 3 of the Declaration is homologous to one of the rights presented by Brierley et al.: the right to flow. ${ }^{129}$ There is also recognition of essential functions within the ecosystem, the connection with groundwater and native biodiversity. ${ }^{130}$ Finally, the declaration includes two rights that point directly to human impacts on rivers: the right to be free from pollution and the right to restoration. ${ }^{131}$

According to Kenneth Kang, the principles in this Declaration are helpful as a starting point or baseline of values and rights that should be recognized for rivers. ${ }^{132}$ However, this does not mean that they provide concrete guidelines for action or for draft legal norms. In fact, because they are so abstract, the rights only offer a visionary reference for judicial cases. In this connection, we believe that these broad guidelines should be nourished by more specific parameters, informed by river sciences and by local knowledge, in order to develop legislation and to ensure that compliance with these rights is site-specific, operative and measurable.

According to the standards and judicial cases analyzed in this study, and on the basis of the common elements of the valuable proposals above, we identify three main categories for the implementation of river rights. These categories have two objectives: first, to orient the determination of legal obligations derived from the rights and to determine who will be 'obliged' to respect and ensure these rights; and second, to identify legal instruments and institutions that might align themselves

124. Poff and others (n 40).

125. Wohl and others, 'The Natural Sediment Regime in Rivers: Broadening the Foundation for Ecosystem Management' (n 54); Wohl and others, 'The Natural Wood Regime in Rivers' (n 54).

126. Brierley and others (n 121).

127. ibid.

128. Earth Law Center, 'Universal Declaration of the Rights of Rivers' (2017) <https://static1. squarespace.com/static/55914fd1e4b01fb0b851a814/t/5a1f2d6ef9619ad38ad18b84/

1519827821379/Universal+Declaration+of+River+Rights+\%28Draft\%29_Oct+2017.pdf > accessed 15 October 2020; Earth Law Center, 'Question \& Answer: Universal Declaration of River Rights' (2017) <https://static1.squarespace.com/static/55914fd1e4b01fb0b851a814/t/ 59de7e6d914e6bbbe2bda609/1507753581572/Universal+Declaration+of+River+Rights+-+Q \%26A_ELC.pdf $>$ accessed 15 October 2020.

129. Earth Law Center, 'Universal Declaration of the Rights of Rivers' (n 128); Brierley and others (n 121).

130. Earth Law Center, 'Universal Declaration of the Rights of Rivers' (n 128).

131. ibid.

132. Kenneth Kang, 'On the Problem of the Justification of River Rights' (2019) 44 Water International $667<$ https://doi.org/10.1080/02508060.2019.1643523>. 
with the effective implementation of the rights of rivers, beyond a mere formal enunciation. These categories are:

1. Rights related to integrity: In terms of flow regime, geomorphology and natural evolution;

2. Rights related to a healthy existence: In terms of decontamination, restoration of physical and biochemical aspects and reparation of human-induced harm;

3. Rights related to biocultural diversity and inter-connection as a social-ecosystem: This category is strongly based on a holistic definition of the river as a natural entity. Understanding the river as a social-ecological system, where humans are an integral component, allows legitimization of the river's connection with diversity in its multiple forms: biological, physical and cultural.

These categories offer a normative vocabulary and taxonomy for constitutional rights that could provide a guideline for transitioning from an anthropocentric theory of human rights to the incorporation of Nature as a holder of legal personhood. Each category could be unpacked into specific rights on a site-specific basis.

The 'integrity rights' address aspects such as the natural flow regime and connectivity (longitudinal, lateral, vertical and temporal) throughout the river network. This category seeks to guarantee the necessary environmental flow, preventing extraction of volumes of water that compromise the existence or integrity of the river and its associated biocultural diversity. This category of rights also aims to protect the river from interventions that would damage its natural channel and floodplain seriously and irreversibly. It is expected that this 'integrity right' would force a judgement to be made between the urgency and necessity of interventions and the level, severity and permanence of their impacts. One of the imperatives for the consideration of the integrity rights would be to establish the obligatory nature of appropriate environmental flows, in accordance both with the particular biogeographical context and with large-scale tendencies of climate change. Existing and novel human activities should be evaluated through a lens that considers the fluvial system at the basin scale, and incorporates it into the scope of protection of other related bodies of water in the basin, such as glaciers, lakes, springs and wetlands. Among the initiatives that should be evaluated, especially in relation to the rights of integrity, are large-scale water transfers or inter-basin 'water highways', large reservoirs or dams that imply a permanent interruption of the flow, mining and industrial infrastructure projects, and the construction of roads that significantly alter the river channel or floodplain. Similarly, activities that demand extraction of water should guarantee the appropriate environmental flow and contemplate legal adaptation mechanisms in the context of climate change. This aspiration is confronted, however, by rigid systems of water allocation, such as in Chile, where water is considered to be a commodity, and water rights are safeguarded as private property. Under this logic, the investment security regulations that protect acquired water rights prevail and allow for water extraction even if this leads to over-exploitation. The integrity rights of a river could force regulation in order to reconcile the real situation of a river with the extraction assignments granted on it.

The second category (rights related to a healthy existence) includes considerations of the biochemical equilibrium of the river and the maintenance of water quality parameters within natural ranges in order to guarantee the subsistence of native aquatic biodiversity and to assure the maintenance of river functions and processes. The measures adopted to fulfil these rights could include restoration actions and decontamination programs. The applicability of such measures must be assessed on a case-by-case 
basis and can be especially difficult to address in advanced stages of environmental degradation and pollution, or where there is an absence of a baseline to enable comparison. In such cases, sources of knowledge from scientific disciplines and local communities should be consulted to determine an acceptable novel ecosystem to aim for with restoration plans. Consideration of the parameters of well-being of a river has a direct impact on the health of all life forms that depend on the river, including human communities, but the consideration of the health of a river as a value in itself allows for the maintenance of these parameters within natural ranges even in the absence of human communities (which is especially important in sparsely populated places). This allows for action in favor of the protection of rivers in an unimpacted state or in the early stages of degradation, even if such impacts have not yet affected human communities, an approach that deepens the application of the precautionary principle in environmental matters. Some of the activities that could be curtailed in the face of these parameters for the healthy existence of rivers are mining activities on diverse scales, sanitary activities that include the presence of sewage discharges, the application of agrochemicals in agricultural and forestry industry, the use of the river ecosystems for crops or for species breeding (such as fish farming), and the extraction of gravel and sand that could modify the sediment transport regime.

Finally, the rights of rivers related to the principles of biocultural diversity and connectivity imply the requirement to protect the relationships and feedback cycles between the river and the social-ecological system of which it is a part. These principles can be an important argument against the criticism regarding the 'confrontation' between rights of Nature and human rights because this approach considers humans to be an inter-dependent part of the fluvial social-ecosystem. The defense of the biocultural diversity and connectivity of a fluvial system can provide the legal basis for actions by communities whose livelihoods depend on a balanced relationship with the river. Extraction is a frequent threat to Indigenous communities throughout Latin America who are faced with investment and infrastructure projects that directly alter this inter-dependence. As an ongoing legacy of colonialism on Indigenous territories and communities the impact of these types of projects is gradually becoming more visible in the light of recent reports of the importance of Indigenous peoples for safeguarding global biodiversity. ${ }^{133}$ This last category of river rights is in perfect agreement with the concept elaborated in Colombia of 'biocultural rights', which constitute a relational category of shared rights between the natural entity (the river) and an associated human community.

All three proposed categories help to articulate human rights debates in light of the recognition of interdisciplinary dialogue and the consideration of Indigenous knowledge. In alignment with the philosophy behind the two existing proposals we argue that future definitions of rights of rivers should draw from local perspectives, both from traditional, local and Indigenous knowledge and from the involvement of national and regional scientists. Part of the situated knowledge that local Indigenous and non-Indigenous communities hold is conserved through the biocultural memory of these communities. ${ }^{134}$ The role of biocultural memory is to provide a long-term historical perspective of the evolution and behavior of natural elements, as well as the relationship that humans have held with respect to their environment. The fields where this type of knowledge has traditionally been analyzed are related to biological

133. IPBES (n 46).

134. Victor Toledo and Narciso Barrera-Bassols, La Memoria Biocultural. La Importancia de Las Sabidurías Tradicionales (Icaria Editorial 2008). 
diversity, linguistic diversity, anthropology and food systems, ${ }^{135}$ while the existence of biocultural memory in the field of river management is an emerging stream of engagement (for scientific institutions). However, the presence of biocultural memory related to river management can be seen through the close connection that some Indigenous communities maintain with fluvial systems, and is expressed in the imperative to consider such local views, evidenced by the spread of social movements and claims supporting the protection and restoration of rivers. Such is the case of the Wayúu people in Colombia ${ }^{136}$ or the Mapuche people in Chile. ${ }^{137}$

Working towards the alignment of judicial rulings concerning the parameters of the well-being of rivers and towards the incorporation of local scientific and non-scientific knowledge, will, we argue, provide a way towards better solutions for river management and protection. Moreover, the genuine consideration of Indigenous peoples' perspectives, although not immune from difficulties, will help to alleviate tensions in cases of conflicts where there is an inextricable connection between Indigenous social movements and environmental defense. ${ }^{138}$

\section{CONCLUSIONS}

Latin America has been able to propose a constitutional regulation of Nature that incorporates the knowledge and worldviews of Indigenous peoples, thus challenging law's generic liberal constitutionalism and Eurocentric roots. The full realization of this shift demands a profound review of the extractivist economic model and the capitalist logic that supports it. This vision from the periphery is uncomfortable for mainstream commitments, but does not have sufficient geopolitical force to change the structures at the global level as yet.

The importance of comparing the three existing paradigms through the case studies analyzed in this article and its underpinning research rests in its provision of evidence of alternative approaches to the legal treatment of Nature. As we have noted, the paradigm in Chile leads to a lack of protection and a failure to recognize social-ecological interconnectedness, while vague recognition is provided merely 'by convenience' as

135. Luisa Maffi, 'Linguistic, Cultural and Biological Diversity' [2005] Annual Review of Anthropology 599.

136. Astrid Ulloa, 'The Rights of the Wayúu People and Water in the Context of Mining in La Guajira, Colombia: Demands of Relational Water Justice' (2020) 13 Human Geography 6; Sergi Vidal, 'The Water Rights-Based Legal Mobilization of the Wayúu against the Cercado Dam: An Effective Avenue for Court-Centered Lawfare from Below?' [2019] Antípoda. Revista de Antropología y Arqueología $45<$ https://revistas.uniandes.edu.co/doi/10.7440/ antipoda34.2019.03>.

137. David Carruthers and Patricia Rodriguez, 'Mapuche Protest, Environmental Conflict and Social Movement Linkage in Chile' (2009) 30 Third World Quarterly 743; Luis Ernesto Cárcamo-Huechante, 'The Value of Swans: Symbolic and Environmental Resistance in Mapuche-Williche Territory' (2008) 24 Latin American Indian Literatures Journal 56; Camila Bañales-Seguel and others, 'Scientific Landscape Related to Mapuche Indigenous Peoples and Wallmapu Territory' (2020) 12 Sustainability $7895<$ https://www.mdpi.com/2071-1050/12/19/ 7895>.

138. Arturo Escobar, 'Sentipensar Con La Tierra: Las Luchas Territoriales y La Dimensión Ontológica de Las Epistemologías Del Sur' (2016) 11 AIBR, Revista de Antropología Iberoamericana 11; Nancy Yáñez and Raúl Molina, Las Aguas Indígenas En Chile (1st ed., LOM Ediciones 2011); Agrawal, 'Indigenous Knowledge and the Politics of Classification' (n 61). 
an effect of the regularization of private water rights within the Water Code framework. Colombia's current paradigm, meanwhile, reflects a transition that at least makes visible the current lack of protection for rivers. Finally, the Constitution of Ecuador provides hope: its model runs contrary to the dominant economic mode. It is not naïve, we suggest, to argue that if protecting Nature is the goal, this paradigm offers a concrete route by assigning legal personhood to natural entities. The promise of the approach is also well exemplified by Article 388 of the Constitution of Ecuador, which specifically indicates the State's responsibility to incorporate scientific knowledge and local Indigenous knowledge in the treatment of Nature.

Overall, the paradigm of the rights of Nature offers a novel perspective for facing the environmental crisis. This paradigm supposes active consideration of local and Indigenous knowledge and norms, which are rooted, and have evolved, in their specific geographical space. These situated knowledge and normative systems are reflected through the recognition of the personhood of natural entities.

Principles such as Buen Vivir and biocultural rights enrich the Latin American panorama and its dialogue with modern constitutionalism. Buen Vivir frames human activity with the understanding of collective, holistic and reciprocal relations with Nature, as seen in constitutions, such as in Ecuador and Bolivia. On the other hand, biocultural rights are a theoretical construction recognizing the deep and intrinsic connection of Indigenous human communities with Nature, through tradition, culture and way of life. For both Buen Vivir and for the biocultural rights paradigm, the impact on rivers, forests, food sources and biodiversity is directly and interdependently related to the right to life and health of situated human communities.

The paradigm of the rights of Nature thus potentially allows for the incorporation of scientific and non-scientific local knowledge in legal deliberations, a consideration that is not a possibility in a model that regards Nature as an object - as is exemplified through the Chilean case, with its utilitarian view of Nature (specifically of water). The articulation between different forms of knowledge will undoubtedly lead to tensions, however, and while a country's constitution can guide a chosen course of action, concrete application will, in practice, require sufficiently adept conflict resolution mechanisms and institutions dedicated to navigating frictions and disputes.

Finally, Latin American constitutional treatment necessarily involves the study and consideration of multiple epistemic frameworks. Proposing ownership of fundamental rights of rivers in the political constitution does not, as demonstrated here, originate in legal categories per se, but rather implies the need for an opening of law to river sciences (which delineate the parameters of river well-being), as well as to Indigenous knowledge and customary law. It is precisely this opening that holds out the hope of progress in the area of fundamental rights jurisprudence in order to bridge the gap between the theory and the practice of river management and protection. 